\title{
Estimation of Timber Production of Five Species of the Tamaulipas Thorny Shrubs Growing in Native Stands and Plantations
}

\author{
Ngangyo Heya Maginot ${ }^{1}$, Foroughbakhch Pournavab Rahim¹, Carrillo-Parra Artemio ${ }^{2}$, \\ Salas Cruz Lidia-Rosaura ${ }^{1}$ \\ ${ }^{1}$ Department of Botany, Faculty of Biological Sciences, University Autonomous of Nuevo León, University Town, \\ San Nicolás de los Garza, Mexico \\ ${ }^{2}$ Laboratory of Wood Tecnology, Faculty of Forestry Sciences, University Autonomous of Nuevo León, Linares, \\ Mexico \\ Email: nheyamaginot@yahoo.fr
}

Received 21 December 2013; revised 2 March 2014; accepted 16 March 2014

Copyright (C) 2014 by authors and Scientific Research Publishing Inc.

This work is licensed under the Creative Commons Attribution International License (CC BY).

http://creativecommons.org/licenses/by/4.0/

c) (i) Open Access

\begin{abstract}
Shrub species have a great capacity to develop in extreme climatic conditions; this ability has a direct influence on their development and productivity in timber and firewood. In this paper, the timber's production of experimental plantation aged 28 years of Acacia berlandieri (Benth.), Havardia pallens (Benth.) Britton \& Rose, Helietta parvifolia (Gray) Benth., Ebenopsis ebano (Berl.) Barneby and Acacia wrightii (Benth.) species is quantified and compared with the production of the same species developed naturally in the native bush. The variables recorded were the number of shoots per tree, total height, basal diameter and diameter at breast height of each tree to determine the volume of wood with the Smalian equation. The results indicate that the volume of usable wood was higher in experimental plantation than that on native vegetation for $H$. parvifolia, $A$. berlandieri and $\boldsymbol{H}$. pallens. The species that produced the highest volume of timber were $H$. parvifolia $\left(0.396 \mathrm{~m}^{3} \cdot \mathrm{ha}^{-1} \cdot\right.$ year $\left.^{-1}\right)$ in plantations and E. ebano $\left(0.118 \mathrm{~m}^{3} \cdot \mathrm{ha}^{-1} \cdot \mathrm{year}^{-1}\right)$ in native shrubs, species with lower production were $H$. pallens $\left(0.059 \mathrm{~m}^{3} \cdot \mathrm{ha}^{-1} \cdot \mathrm{year}^{-1}\right)$ and $A$. berlandieri $\left(0.052 \mathrm{~m}^{3} \cdot \mathrm{ha}^{-1} \cdot \mathrm{year}^{-1}\right)$ in the native area. The highest number of shoots was registered for $A$. berlandieri and $H$. parvifolia, with eight shoots per tree in experimental plantations of both species compared with native vegetation, which was five and three shoots per tree respectively. These results high-light the importance of developing plantations in degraded areas of scrub, which can increase timber volume production.
\end{abstract}

\section{Keywords}

Timber, Shoots, Tamaulipas Thorny Scrub, Plantation, Native Vegetation

How to cite this paper: Maginot, N. H., et al. (2014). Estimation of Timber Production of Five Species of the Tamaulipas Thorny Shrubs Growing in Native Stands and Plantations. Open Journal of Forestry, 4, 239-248. 


\section{Introduction}

Selection of native tree species for non industrial use in developing countries has become an important issue due to the recent world awareness of the importance of forestry to rural development and the pressure to achieve useful results in a quick manner (Burley \& Von Carlowitz, 1984; Tewari et al., 2000). Not only experienced staff is needed but clearer conservation and restoration policies, management techniques and funds for supporting them are necessary as well. Besides, reliable information on ecological, silvicultural and other useful characteristics of many potentially valuable species is still unavailable and hampers species selection (Booth, 1985; Woerner, 1991).

The Tamaulipas thorny shrubs of northeastern Mexico are one of the most abundant vegetation types with the more history of use in Mexico (García, 2004; Rzedowski, 1978), covering an area of 125,000 km² of the Gulf Coastal Plain of Mexico in the north-east of the country and the southern tip of Texas, USA (Ruiz, 2005). This ecosystem is quite diverse in number, density and height of trees, shrubs and sub-shrubs (Alanís, 2006).

The Tamaulipas thorny shrubs are used for a wide variety of purposes in all the silvopasture, where anthropogenic influence has marked different patterns of use, such as the production of fodder, fuel wood, shelving, timber, construction materials, food and traditional medicine as well as the selective species extraction (Foroughbakhch \& Heiseke, 1990). The use of this kind of scrub without silvicultural practices has led erosion, de- struction and/or conversion of large areas (Andrade et al., 2001; Vale et al., 2004). These actions are undoubt- edly due to ignorance of the growth patterns of the species, which is why cover many areas of scrub and are still used primarily for agricultural purposes and/or livestock, whose economic returns are short-term.

Having knowledges of the scrub's characteristics provides a holistic view of forestry and agroforestry opportunities to apply properly in each area (Guevara-Escobar et al., 2007), considering reliable projections of growth and returns for excellent management planning, improvement and use of these resources.

In this context, the objective of this study is to evaluate the growth and volume production of scrub's native species, both in plantations and in the native vegetation, with specific objectives: 1) to study the development in height, diameter and volume of experimental plantation and native vegetation, 2) to evaluate the production of shoots of the studied species at each site and 3) to determine the correlations height-diameter, diameter-shoots.

\section{Materials and Methods}

\subsection{Description of the Study Area}

The experimental area is located on a plain region at 430 - $450 \mathrm{~m}$ altitude in the piedmont of the Sierra Madre Oriental in Mexico (24 $47^{\prime}$ north latitude and $99^{\circ} 32^{\prime}$ west longitude). Originally all the area was covered by the typical Tamaulipan thornscrub dominated by woody plants which was mostly cleared to support cattle production and crops systems. Some areas with perennial shrubs and plants were conserved as reserves and others were used for agroforestry activities and ecological studies. The regional climate in the scheme of Köppen modified by García (2004) is defined as semiarid and subhumid [(A) C (Wo)] with two rainy seasons (summer and autumn) and a dry spell between November and April. Mean annual precipitation is 780 mm (Cavazos \& Molina, 1992). The month with the highest mean rainfall is September (180 - $200 \mathrm{~mm})$ and the lowest occurs in December and January (15 - $20 \mathrm{~mm})$. Average number of days with rainfall per year is $85 \pm 15$. About half of these days show precipitation amounts of less $5 \mathrm{~mm}$, mainly related to thunderstorms resulting from deep convection by mid-latitude disturbances (Navar et al., 1999). Cold-front systems determine most of the winter rainfall, accounting for $<10 \%$ of the long-term annual average. Potential evapotranspiration, is -1150 mm (Navar \& Bryan, 1994). The mean annual temperature is $22.3^{\circ} \mathrm{C}$ with a large difference between winter and summer (abs. min. $12^{\circ} \mathrm{C}$, abs. max. $45^{\circ} \mathrm{C}$ ) and even within the same month. Hail and frosts usually occur every year even after the beginning of the growing season in March. The water budget is unbalanced. The ratio of precipitation to free evaporation is 0.48 and precipitation to potential evaporation is 0.62 . Soils of the region mostly derive from rocks of the Upper Cretaceous rich in calcite and dolomite. The dominant soils are deep, dark grey, lime-clay vertisols which are the result of alluvial and colluvial processes (FAO-UNESCO, 1974; Navar, 2003) characterized by high clay and calcium carbonate content (pH 7.0 - 8.0) and low organic matter content. Analysis of major nutrients reveals phosphorus and nitrogen deficiencies. Nitrogen is very volatile in the prevailing climate and it is apparently lost when the vegetation is cleared from sites with diverse species of woody legumes, leaving the soil exposed to alternating conditions of heavy rain and extreme isolation. Such soils can be $3 \mathrm{~m}$ deep or more 
and are preferred for agricultural seepage. Underground water is hard, but non-saline (Woerner, 1991). Vegetation associated to the study area is described as dense $\left(2.0-6.4\right.$ shrubs $\left.\cdot \mathrm{m}^{-2}\right)$, shrubby (average height of 1.95 $2.63 \mathrm{~m}$ ) and diverse. Most plant species overlap vertically from 0.5 to $5.0 \mathrm{~m}$ (Manzano, 1997; De Soyza et al., 1997) and horizontally average distance between shrubby stems is $30 \mathrm{~cm}$ while mean crown radius is $47 \mathrm{~cm}$, resulting in a mean overlapping radius of $17 \mathrm{~cm}$. Average open space between shrub canopies is $10 \mathrm{~cm}$. The altitude is $350 \mathrm{~m}$ above sea level. The vegetation is divided into thorny high scrub, with lateral spines, where Acacia rigidula and A. berlandieri are dominant, and medium scrub with Cordia boissieri and Pithecellobium pallens as dominant species (Foroughbakhch \& Heiseke, 1990). Figure 1 shows the location of the study area.

\subsection{Methods}

\subsubsection{Selection of Species}

The choice of the species to be studied in an area was made only after careful consideration of their adaptability, growth rate, and their potential use by local people as timber for construction and firewood. Furthermore, general utility species combine adequate shape with structural strength and durability. Thus, five species selected in the experiment are native to arid and semi-arid zones in Mexico and adjacent USA. Table 1 shows information about the name, family and the wood characteristics of each of these species.

\subsubsection{Experimental Design}

The sample consisted of 15 plots in experimental plantations with native species and 12 plots in native vegetation, at three plots per species in each area. There are 25 trees per plot of experimental plantations, with a separation of $3 \mathrm{~m}$ between them. In plots of native area, there is variability in number of trees as spacing between them.

According to Foroughbakhch and Heiseke (1990), the native vegetation was beginning its development when the plantation was made.

Figure 2 shows the field record of the number of shoots per tree, total height, diameters basal and at breast height in both areas. These data were recorded from March to June 2013, at 28 years after plantation. Timber and firewood volume were estimated based on each yield plant $^{-1}$. species $^{-1}$ (standing without cutting the tree) taking into account all of those trunks with a length of $1.8 \mathrm{~m}$ or higher and $0.1 \mathrm{~m}$ in diameter in both upper and lower extremes, as it is considered a suitable commercial size for constructions in the rural areas in Mexico, using the Smalian equation (Moctezuma, 2007) with a 0.6 of morphic coefficient factor.

Equation (1) is the formula used to calculate this volume.

$$
\mathrm{V}=\left\{\left[\left(\mathrm{D}_{1} / 2\right)^{2} \times \pi+\left(\mathrm{D}_{2} / 2\right)^{2} \times \pi\right] / 2\right\} \times \mathrm{L}
$$

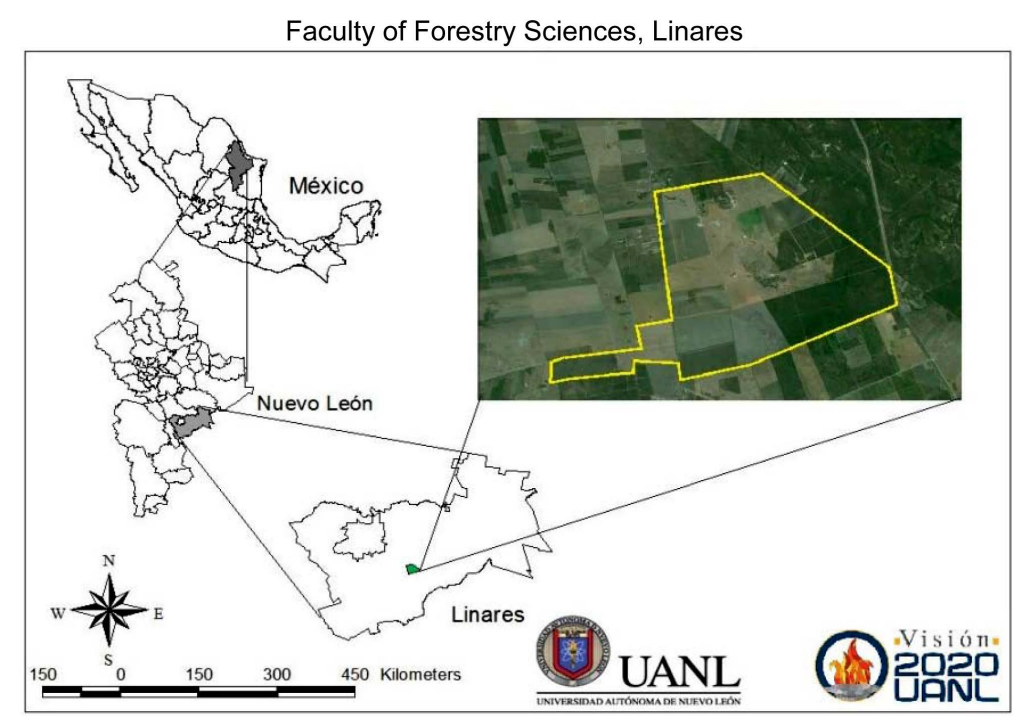

Figure 1. Location of the study area (Source: Authors of this paper). 
Table 1. Characteristics of the five woody plant species selected for study.

\begin{tabular}{|c|c|c|c|}
\hline Family & Species & Characteristics \& life form & Uses \\
\hline Mimosaceae & $\begin{array}{l}\text { Acacia berlandieri } \\
\text { Benth. }\end{array}$ & $\begin{array}{l}\text { Spiny shrub }(2-5 \mathrm{~m}), 8-10 \mathrm{~cm} \text { in diameter invading } \\
\text { grasses, fuelwood, natural hardness resistant for rural } \\
\text { wood construction, distributed in northeastern and } \\
\text { central Mexico. }\end{array}$ & Handicrafts Firewood, forage. \\
\hline Mimosaceae & $\begin{array}{l}\text { Acacia wrightii } \\
\text { Benth. }\end{array}$ & $\begin{array}{l}\text { Spiny tree/shrub } 6 \text { - } 8 \mathrm{~m}(12 \mathrm{~m}), 10 \text { - } 30 \mathrm{~cm} \text { in diameter, } \\
\text { distributed in northern Mexico and southern Texas, USA. }\end{array}$ & $\begin{array}{l}\text { Firewood, Charcoal, Handcrafts, } \\
\text { Food (seeds), wood, forage. }\end{array}$ \\
\hline Mimosaceae & $\begin{array}{l}\text { Ebenopsis ebano } \\
\text { (Berl.) Barneby }\end{array}$ & $\begin{array}{l}\text { Tree } 4 \text { - } 10(15) \mathrm{m}, 50(120) \mathrm{cm} \text { diameter, hardwood, dark } \\
\text { with a very good natural resistance. Distributed in northern } \\
\text { Mexico, southwestern Texas, in the lowlands. }\end{array}$ & $\begin{array}{l}\text { Posts, Firewood, Charcoal, Wood } \\
\text { (furniture), shade for animal } \\
\text { protection, Food (fruit \& pods). }\end{array}$ \\
\hline Mimosaceae & $\begin{array}{l}\text { Havardia pallens } \\
\text { (Benth.) Britton \& Rose. }\end{array}$ & $\begin{array}{l}\text { Spiny shrub } 3 \text { - } 5 \text { (8) m, dense wood, low natural } \\
\text { resistance. Distribution north and northeastern Mexico } \\
\text { and southern Texas. }\end{array}$ & $\begin{array}{l}\text { Firewood, construction and } \\
\text { manufacture of furniture. }\end{array}$ \\
\hline Rutaceae & $\begin{array}{l}\text { Helietta parvifolia } \\
\text { (Gray.) Benth. }\end{array}$ & $\begin{array}{l}\text { Large shrub or small tree } 2 \text { - } 10(12) \mathrm{m} \text {, early invader in } \\
\text { calcareous soils, deep root system with very high natural } \\
\text { resistance of wood, is distributed in northeastern } \\
\text { Mexico and Texas. }\end{array}$ & $\begin{array}{l}\text { Poles, shelves, wood, } \\
\text { Charcoal, medicinal. }\end{array}$ \\
\hline
\end{tabular}

Sources. Hormazabal (1986), Niembro (1990), and Velazco et al. (2011).

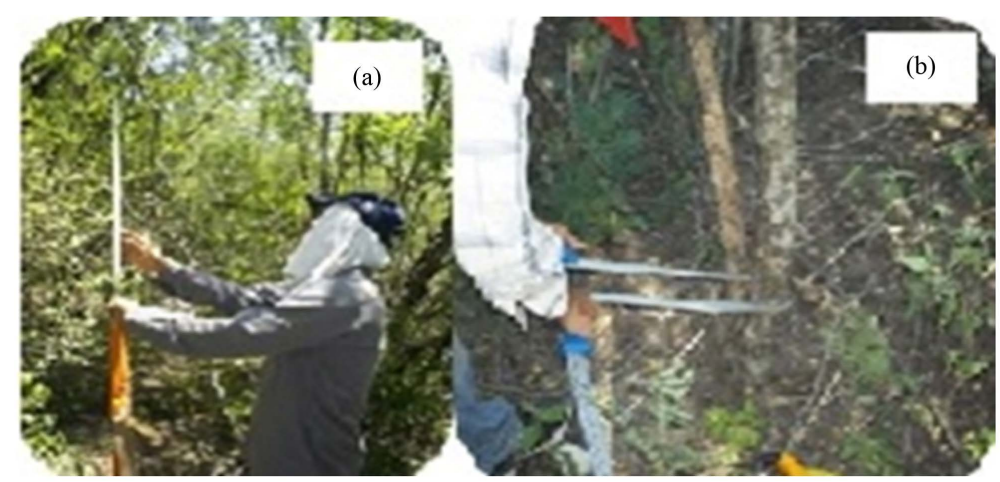

Figure 2. Measurements for estimation of volume: (a) measuring of total height with beacon, (b) measuring of diameters with vernier.

where $D_{1}$ and $D_{2}$ are the diameters of each end $(\mathrm{cm})$, and $L$ is the length of the section $(\mathrm{m})$.

Once obtained the volume per tree, the mathematical process was realized to estimate the timber volume for each species.

\subsubsection{Statistical Analysis}

The growth measurement parameters and the volume were calculated per shoot and then per tree, for each species per plot, and estimated per hectare. An analysis of variance was applied to test hypotheses about growth variables and productivity between species and sampling sites along a gradient of site quality. Contrast tests were used to compare the mean values (Hinkelmann \& Kempthorne, 1994). The data were analyzed with the statistical package SPSS (v. 21.0). Duncan's Multiple Range Test (DMRT) was carried out in some cases. Least significant differences were calculated at 5\% probability level (LSD 0.05) according to Zar (2010).

\subsection{Results}

\subsubsection{Shoots Capacity}

The ability to produce shoots is considered as one of the main attributes of shrubs, to be established and maintained after each cut and/or frost damage, drought, fire, etc. The management of shoots has an influence on the vegetative regeneration and growth. Figure 3 presents the results of the number of shoots per tree. 


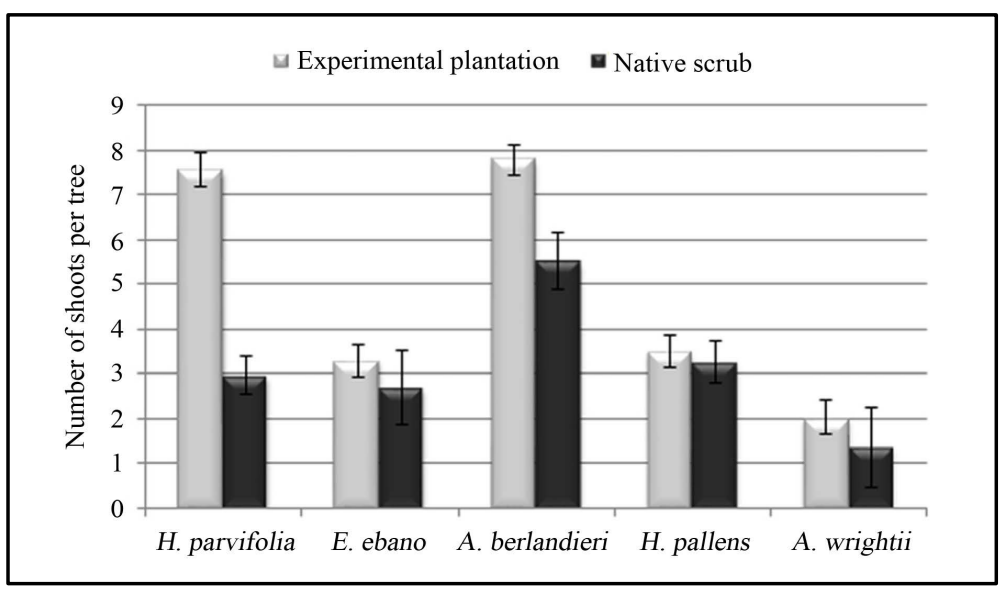

Figure 3. Average number of shoots and standard deviation per specie at each site.

Table 2 indicates that there was a highly significant difference $(P<0.01)$ between species, sites and the interactions (Site $\times$ Species), regarding to the production of shoots. The experimental plantations have presented the highest number of shoots, with an average of five shoots per tree, while in the native scrub, there were three shoots per tree. Acacia berlandieri and Helietta parvifolia were the species that developed the largest number of shoots, with an average of seven and five shoots per tree respectively, while Acacia wrightii generally had a single stem.

\subsubsection{Height Growth}

The height growth has a great influence on the competitive power of a specie, and increase the volume. Figure 4 presents the average height of each species per site.

Table 3 presents the results of analysis of variance on height growth, which reveals the existence of a highly significant difference $(P<0.01)$ between the species studied. However, between sites, was not detected significant difference $(p=0.126)$. The species under forest plantation conditions reached a height of $4.25 \mathrm{~m}$ on average, compared to $4.30 \mathrm{~m}$ in the native vegetation.

In general, the average height was $4.27 \mathrm{~m}$ at both sites, Ebenopsis ebano and Helietta parvifolia were the species that showed the higher height, with 5.24 and $4.90 \mathrm{~m}$ respectively.

\subsubsection{Growth in Diameter}

The diameter of trees is a very important parameter for forest, this indicate the potential use. Figure 5 shows the diameter of studied species, both basal (a) and at breast height (b).

Table 4 and Table 5 show variability in the diameter increment both between species and between sites, being highly significant difference with a probability close to zero. The average basal diameter (Db) was $5.59 \mathrm{~cm}$ in the experimental plantations and $5.20 \mathrm{~cm}$ in native vegetation, while the diameter at breast height (DBH) was $3.83 \mathrm{~cm}$ in the experimental plantations and $3.86 \mathrm{~cm}$ in the native vegetation, being Ebenopsis ebano and Acacia wrightii the species of higher diameter both basal and at breast height with 10.28 and $8.86 \mathrm{~cm}(\mathrm{Db}), 7.74 \mathrm{and}$ $6.04 \mathrm{~cm}(\mathrm{DBH})$, respectively.

In assessing the increase in diameter of four species by counting the growth rings at breast height, Foroughbakhch \& Heiseke (1990) evaluated two scrub communities in the region of Linares: "scrub plain” and "scrub on the hill”. These authors found that for a tree to reach a DBH of $6.5 \mathrm{~cm}$ should be allowed after 16 years on the plains and 32 years on the mound. For certain species of this study as E. ebano and A. wrightii, the results are more near with those of the hill. Other species are not satisfied with this conclusion.

\subsubsection{Timber Volume}

Figure 6 presents the volumetric production of species studied. Table 6 shows that the timber volume production was not presented statistically significant difference between sites $(P>0.05)$. However, this volume was different between species. Helietta parvifolia produced $0.396 \mathrm{~m}^{3} \cdot \mathrm{ha}^{-1} \cdot \mathrm{year}^{-1}$, and the lower production was rec- 
N. H. Maginot et al.

Table 2. Analysis of variance of number of shoots per tree depending on species and sites.

\begin{tabular}{cccccc}
\hline Source of variation & Sum of squares & df & Mean square & F & $P$ \\
\hline Intersection & 4741.046 & 1 & 4741.046 & 533.987 & 0.000 \\
Site & 206.907 & 1 & 206.907 & 23.304 & 0.000 \\
Species & 875.159 & 4 & 218.790 & 24.642 & 0.000 \\
Site * Species & 303.467 & 4 & 75.867 & 8.545 & 0.000 \\
\hline
\end{tabular}

Table 3. Analysis of variance of growth in height depending on species and sites.

\begin{tabular}{cccccc}
\hline Source of variation & Sum of squares & $\mathrm{df}$ & Mean square & F & $P$ \\
\hline Intersection & 5582.151 & 1 & 5582.151 & 5493.963 & 0.000 \\
Site & 2.391 & 1 & 2.391 & 2.353 & 0.126 \\
Species & 136.874 & 4 & 34.218 & 33.678 & 0.000 \\
Site * Species & 48.936 & 4 & 12.234 & 12.041 & 0.000 \\
\hline
\end{tabular}

Table 4. Analysis of variance of growth in basal diameter of the species according to the study sites.

\begin{tabular}{cccccc}
\hline Source of variation & Sum of squares & df & Mean square & F & $P$ \\
\hline Intersection & 11355.280 & 1 & 11355.280 & 1600.482 & 0.000 \\
Site & 90.899 & 1 & 90.899 & 12.812 & 0.000 \\
Species & 2110.337 & 4 & 527.584 & 74.361 & 0.000 \\
Site * Species & 433.875 & 4 & 108.469 & 15.288 & 0.000 \\
\hline
\end{tabular}

Table 5. Analysis of variance of growth in diameter at breast height.

\begin{tabular}{ccccc}
\hline Source of variation & Sum of squares & df & Mean square & F \\
\hline Intersection & 5866.758 & 1 & 5866.758 & 1224.739 \\
Site & 111.279 & 1 & 111.279 & 23.231 \\
Species & 1149.875 & 4 & 287.469 & 0.000 \\
Site $*$ Species & 321.523 & 4 & 80.381 & 0.000 \\
\end{tabular}

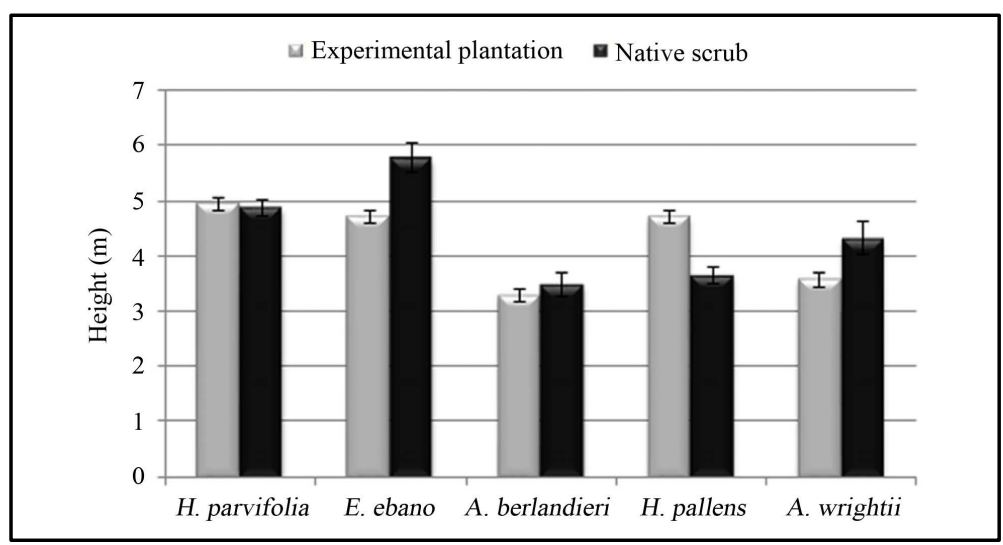

Figure 4. Growth in average height and standard deviation of species per site. 


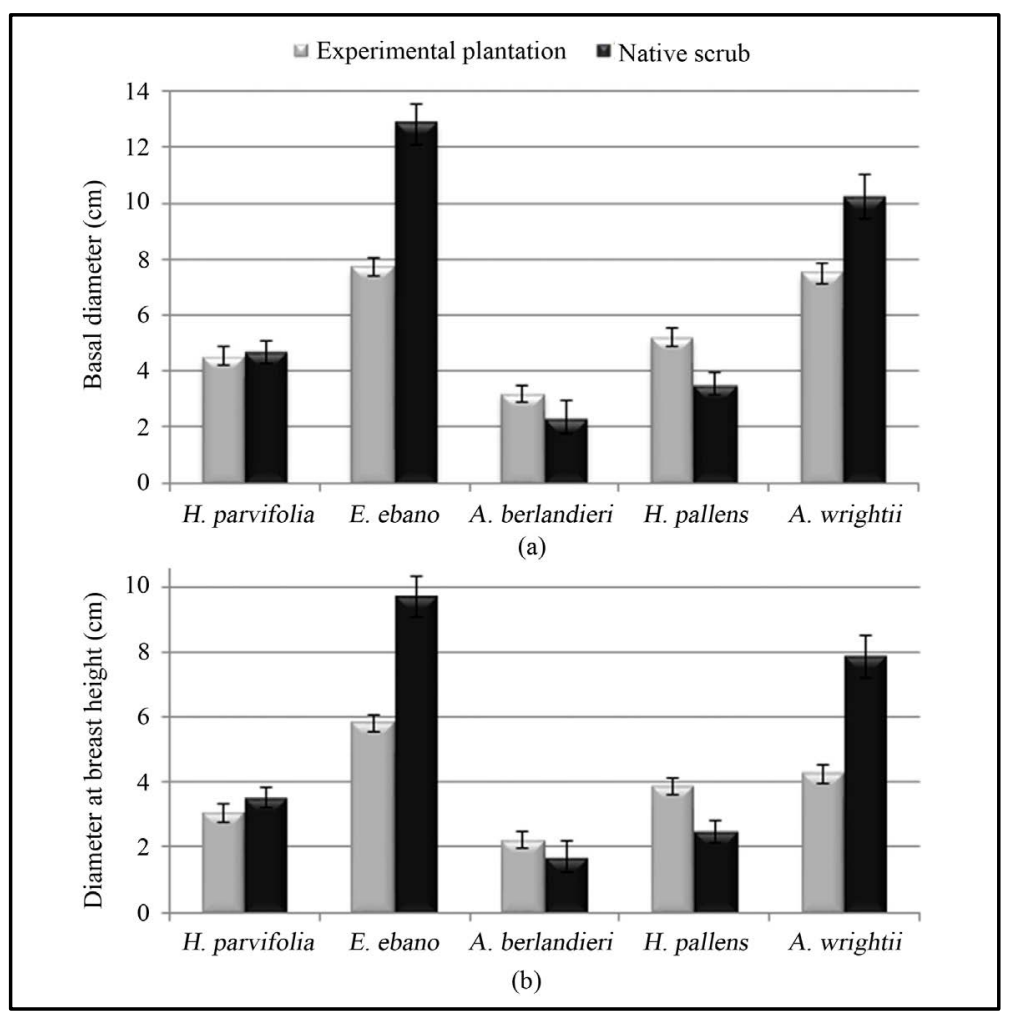

Figure 5. Diameter growth by species at both sites: (a) basal diameter, (b) diameter at breast height.

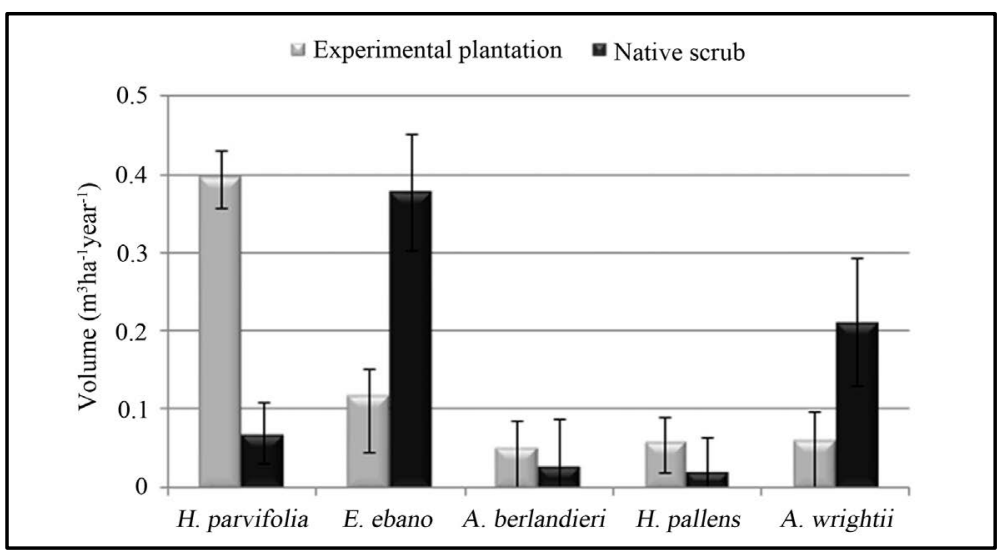

Figure 6. Average volume of wood produced according to species and sites.

orded the species Acacia berlandieri and Havardia pallens, with 0.052 and $0.059 \mathrm{~m}^{3} \cdot \mathrm{ha}^{-1} \cdot \mathrm{year}^{-1}$ respectively, in the native vegetation.

The timber volume was higher in the native site compared with experimental plantation found for the species E. ebano and A. wrightii with 0.377 against $0.118 \mathrm{~m}^{3} \cdot \mathrm{ha}^{-1} \cdot \mathrm{year}^{-1}$ and 0.211 against $0.061 \mathrm{~m}^{3} \cdot \mathrm{ha}^{-1} \cdot \mathrm{year}^{-1}$, respectively.

\section{Discussion}

Along with survival, a further criterion to evaluate the development of woody species for forestry programs is height and diameter growth. These parameters are proper indicators of the site conditions (soil and climate) although they are also dependent on factors such as interspecific competition, standard density (spacing) and cli- 
Table 6. Analysis of variance of timber volume depending on species and sites.

\begin{tabular}{cccccc}
\hline Source of variation & Sum of squares & $\mathrm{df}$ & Mean square & $\mathrm{F}$ & $P$ \\
\hline Intersection & 5.752 & 1 & 5.752 & 80.414 & 0.000 \\
Site & 0.001 & 1 & .001 & 0.019 & 0.890 \\
Species & 3.089 & 4 & .772 & 10.795 & 0.000 \\
Site * Species & 3.451 & 4 & .863 & 12.063 & 0.000 \\
\hline
\end{tabular}

matic conditions. The latter factor seems to determine the growth and development of the evaluated species in northeastern Mexico.

According to Martínez et al. (2006), the purpose of the establishment of forest plantations worldwide is to satisfy the demand for industrial raw materials, household, production of fodder, building poles and/or wood as fuel. Generally in this study, is confirmed this approach.

It was found that the number of shoots per tree was higher in the experimental plantation than native vegetation. Ebenopsis ebano and Acacia wrightii showed a low number of shoots, that can be attributed to the greater spacing between trees in this community, which results in less competition, and which favors the uptake of light and nutrients needed for the formation of new shoots. Estévez (2004) relates the smallest number of shoots in the "Barrosa", to the damage for different agents as lignotuber that manifested a lack of shoots. This can be noted also, for frost that occurred in the study site.

Similar studies have been realized by Ruiz (2005), who established that the average height of the shrubs species was $3.28 \mathrm{~m}$, featuring $H$. pallens as the species of greatest height $5 \mathrm{~m}$. For his part, Garcia (2004) recorded an average height of $3.2 \mathrm{~m}$, with $\mathrm{H}$. pallens as the specie of more height $5.8 \mathrm{~m}$, because the study was conducted at sites near the "Sierra Madre Oriental" which makes this species more dominant and therefore present greater height.

Moreover, the data corresponding to the diameter of the species showed the opposite, larger diameters were presented in native vegetation. However, the results indicate that the species whose number of shoots is lower, showed higher diameter both basal (Db) and at breast height (DBH). This is shown in Ebenopsis ebano and Acacia wrightii, which recorded respectively an average of three and two shoots per tree, with basal diameters (Db) of 10 and nine $\mathrm{cm}$ respectively, and at breast height (DBH) of eight and six cm respectively. These results agree with those reported by Estévez (2004), who relates that the number of shoots decreased with the diameter increasing. Thus the species with the highest number of shoots have smaller diameters. This is remarkable in Acacia berlandieri, which recorded the highest number of shoots (seven shoots per tree), but with average diameters of $2.77 \mathrm{~cm}(\mathrm{Db})$ and $1.97 \mathrm{~cm}(\mathrm{DBH})$.

For their part, Foroughbakhch \& Heiseke (1990) mention that the plantation development in both height and diameter was affected by frost that occurred during the 1987-1988 winter periods.

This could explain that in certain parameters, the results do not reflect the expected in plantations, compared with native scrub where species are more vigorous.

As for the volume of timber, Carrillo (1991) noted that Ebenopsis ebano produced $3.67 \mathrm{~m}^{3} \cdot \mathrm{ha}^{-1}$, and A. berlandieri $3.42 \mathrm{~m}^{3} \cdot \mathrm{ha}^{-1}$, which was almost equal. In 22 years, a difference is marked between the production of these two species, E. ebano $\left(.377 \mathrm{~m}^{3} \cdot \mathrm{ha}^{-1} \cdot \mathrm{year}^{-1}\right)$ and A. berlandieri $\left(.052 \mathrm{~m}^{3} \cdot \mathrm{ha}^{-1} \cdot \mathrm{year}^{-1}\right)$, which presents $E$. ebano as a species with good potential for timber use.

\section{Conclusion}

Knowledge about the development of species in forest plantation is an indispensable requisite for the optimal design of scrub management strategies for adequate production.

The ability to produce shoots of scrub species is related to its adaptability to site conditions and their productive potential. It was found that trees with larger numbers of shoots present higher timber volume. But the fewer number of shoots favors a good development in individual girth. However, highly extreme ecological factors have an indubitable influence on some scrub species, as clearly demonstrated by the results of this study.

It should be noted that the high capability of reproduction through resprouting mechanism plays an important 
role in the production of biomass of scrub species and therefore in erosion controlling, water regime stabilizing, or simply contributes in the conservation of the protective functions of the forest ecosystem. The application of silvicultural treatments could contribute significantly to the increase of the biomass in forest plantations.

However, the preference of one species to the other(s) can be driven by the desired use of the resource. So, for the production of shoots, Helietta parvifolia and Acacia berlandieri could be advisable in plantations, because of their greater number of these. For the height and timber volume in general, $H$. parvifolia in plantation, and $E$. ebano in the native vegetation are the best species. In terms of diameter, E. ebano and A. wrightii have good timber possibilities in the native vegetation.

\section{References}

Alanís, R. E. (2006). Diversidad de especies arbóreas y arbustivas en áreas con distinto historial antropogénico en el matorral espinoso tamaulipeco. Tesis de maestría. UANL.

Andrade, C. M. S., Garcia, R., Couto, L., \& Pereira, O. G. (2001). Fatores limitantes ao crescimento do capim-Tanzania em um sistema agrossilvipastoril com eucalipto, na regiao dos Cerrados de Minas Gerais. Revista Brasileira de Zootecnia, 30, 78-85. http://dx.doi.org/10.1590/S1516-35982001000500007

Booth, T. H. (1985). A New Method for Assisting Species Selection. Commonwealth Forestry Review, 64, 241-250.

Burley, J., \& Von Carlowitz, P. (1984). Multipurpose Tree Germoplasm. Nairobi: ICRAF.

Carrillo, P. A. (1991). Efecto de algunos tratamientos silvícolas y de factores abióticos sobre la regeneración y manejo del matorral. Tesis, ingeniería forestal, Linares: Facultad de Ciencias Forestales, UANL.

Cavazos, M. T., \& Molina, V. (1992). Registros climatológicos de la región citrícola de NuevoLeón. Boletín Técnico, 1, $1-65$.

De Soyza, A. G., Whitford, W. G., Martinez, M. E., \& Van Zee, J. W. (1997). Variation in Creosote Bush (Larrea tridentate) Canopy Morphology in Relation to Habitat, Soil Fertility and Associated Annual Plant Communities. American Midland Naturalist Journal, 137, 13-26. http://dx.doi.org/10.2307/2426751

Estévez, I. (2004). Estudio dendroecológico y estructural de Erica australis L. Trabajo de Investigación Tutelado. Universidad de Santiago de Compostela.

FAO-UNESCO (1974). Soil Map of the World (Vol. I). Paris: UNESCO.

Foroughbakhch, R., \& Heiseke, D. (1990). El matorral como recurso forestal. Reporte Científico No. 1 (1985)—Reimpresión 1990. Facultad de Ciencias Forestales, UANL, 31 p.

García, E. (2004). Modificaciones al sistema de clasificación climática de Koppen para adaptarlo a las condiciones de la República Mexicana (3r ed., 252 p). México D.F.: UNAM.

Guevara-Escobar, A., Kemp, P. D., Mackay, A. D., \& Hodgson, J. (2007). Pasture Production and Composition under Poplar in a Hill Environment in New Zealand. Agroforestry, 69, 199-213. http://dx.doi.org/10.1007/s10457-007-9038-9

Hinkelmann, K., \& Kempthorne, O. (1994). Design and Analysis of Experiments. Introduction to Experimental Design (Vol. 1). New York: John Wiley \& Sons.

Hormazabal, F. (1986). Especies forestales exóticas de interés económico para Chile (Vol. 32). Santiago: Instituto Forestal, 61-111.

Manzano, M.G. (1997). Procesos de desertificación asociados a sobre pastoreo por caprinos en el matorral espinoso de Linares, Nuevo León. Master's Thesis, Facultad de Ciencias Forestales, Mexico: UANL.

Martínez, R., Azpiroz, R., Rodríguez de la, O., Cetina, A., \& Gutiérrez, E. (2006). Importancia de las Plantaciones Forestales de Eucalyptus. Ra Ximhai Revista de Sociedad, Cultura y Desarrollo Sustentable. Universidad Autónoma Indígena de México.

Moctezuma, L. G. (2007). Primer ciclo de seminarios de investigación del CENID-COMEF. México DF: En Memorias de Seminario INIFAP-CENID, 38 p.

Navar, J., \& Bryan, R. B. (1994). Fitting the Analytical Model of Rainfall Interception of Gash to Individual Shrubs of Semi-Arid Vegetation in Northeastern Mexico. Agricultural and Forest Meteorology, 68, 133-143. http://dx.doi.org/10.1016/0168-1923(94)90032-9

Navar, J., Charles, F., \& Jurado, E. (1999). Spatial Variations of Interception Loss Components by Tamaulipan Thornscrub in Northeastern Mexico. Forest Ecology and Management, 124, 231-239. http://dx.doi.org/10.1016/S0378-1127(99)00077-8

Navar, C. J. (2003). Información directa de Control Hidrológico de la Región. Linares, NL: Facultad de Ciencias Forestales, UANL. 
Niembro-Rocas, A. (1990). Árboles y arbustos útiles de México. Mexico, DF: Limusa, 206.

Ruiz, J. L. (2005). Caracterización estructural del Matorral Espinoso Tamaulipeco, Linares N.L. Tesis de Maestría. FCF_ UANL.

Rzedowski, J. (1978). Vegetación de México. México, DF: Limusa.

Tewari, J. C., Harris, P. J. C., Harsh, L. N., Cadoret, K., \& Pasiecznik, N. M. (2000). Managing Prosopis juliflora (Vilayati babul). A Technical Manual. Jodhpur: Central Arid Zone Research Institute and Coventry: HDRA.

Vale, R. S., Couto, L., Silva, M. L., Garcia, R., Almeida, J. C. C., \& Lani, J. L. (2004). Ana'lise da viabilidade economica de um sistema silvipastoril com eucalipto para a Zona da Mata de Minas Gerais. Agrossilvicultura, 1, 107-120.

Velazco-Macías, C. G., Alanis-Flores, G., Alvarado-Vázquez, M., Ramírez-Freire, L., \& Foroughbakhch-Pournavab, R. (2011). Endemic Flora from Nuevo León, Mexico and Adjacent States. Journal of the Botanical Research Institute of Texas, 5, 275-298.

Woerner, M. (1991). Los suelos bajo vegetación del matorral del noreste de México, descritos a través de ejemplos en el Campus Universitario de la UANL. Reporte Científico No. 22 Facultad de Ciencias Forestales, UANL, 116 p.

Zar, J. H. (2010). Biostatistical Analysis (5th ed.). New Jersey: Prentice-Hall, Inc., 947. 